plan 20 years ago, in an exercise that led to the construction of a string of projects. Although it still starts up some mediumsized facilities - such as the nanotechnology facility for which Orbach and his boss, energy secretary Spencer Abraham, broke ground last week at Oak Ridge National Laboratory in Tennessee - it has no overall plan for larger ones.

Last December, Orbach sent out a letter to advisory groups asking them to suggest new facilities that the directorate could build. "Creating these facilities for the benefit of science is at the core of our mission," the letter read.

The response was enthusiastic, according to University of Oregon chemist Geraldine Richmond, who chairs the department's basic energy sciences advisory committee. Among the facilities recommended by Richmond's committee is a series of new light sources to probe materials and molecules.

At the top of the nuclear physicists' list is the Rare Isotope Accelerator, which would carry out experiments on highly unstable nuclei in an effort to reproduce nuclear reactions inside stars and supernova explosions. Planning for the machine has been hampered by budget problems and uncertainty over when it will be built, says Richard Casten, a nuclear physicist at Yale University who heads the nuclear science advisory group. "My feeling is that maybe what Orbach's doing can change that," he says.

At a cost of about $\$ 800$ million, the isotope accelerator would be one of the more ambitious projects under consideration, but it is by no means the most expensive. Also being considered are a \$5-billion experimental fusion reactor known as ITER, and a \$6-billion linear collider for high-energy physics.

Martha Krebs, who served in Orbach's position under the Clinton administration from 1993 to 1999 and is now a consultant in Los Angeles, says: "Putting out a preferred list will be very difficult to do." She tried to draw up a similar list of facilities during her tenure, but ran into difficulties with the energy secretary and the White House Office of Management and Budget, whom she says wouldn't approve a plan that called for billions of dollars in additional spending.

At that time, support in Congress was weak for both the energy department and its science office - but that may be changing, Krebs says. The House of Representatives has just approved a $6.5 \%$ increase for DOE science (see page 561), and congressional staff members who oversee the department are eager to see what facilities plan the department can come up with. "I'm dying to see how they're going to handle this," says one.

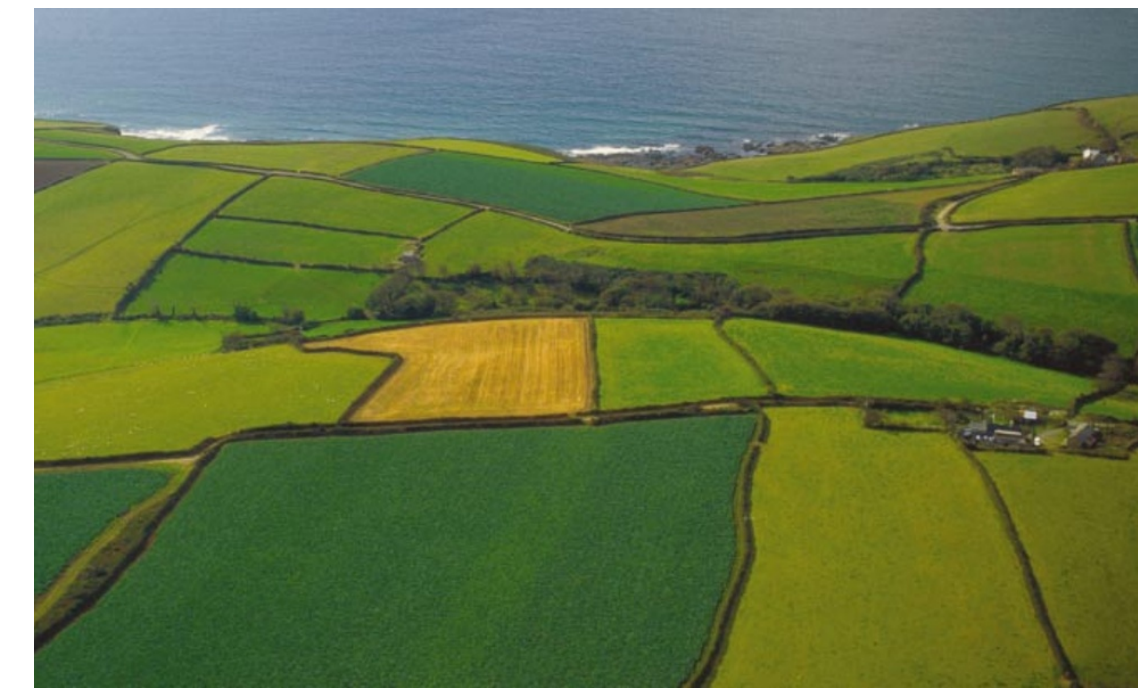

Green issue: scientists say that transgenic crops' effects on farmland are their most pressing concern.

\title{
UK experts map out route to licensing transgenic crops
}

\section{Jim Giles, London}

There are no human-health grounds for holding up the planting of transgenic crops in Britain, an expert panel has told the UK government.

But the panel said that the crops could have adverse environmental impacts, and should only be grown after case-by-case assessments of the risks. Its findings, released on 21 July, are expected to influence the government's decision on whether to license some transgenic crops for commercial planting later this year.

The panel was chaired by the government's chief scientific adviser, David King. Its work is part of a three-pronged assessment of transgenic crops by the UK government, which has also included a report issued on 11 July on the crops' economic impact, and a public consultation involving 500 meetings held around the country.

The process is being watched closely because British consumers' rejection of the technology is influencing its adoption in many other countries. "This will be influential internationally," says plant scientist Mark Tester of the University of Cambridge.

But it remains unclear whether the panel's tentative green light for the technology will be enough to open the door to British cultivation of transgenic crops any time soon. Prime Minister Tony Blair has advocated the technology, but his unpopularity in the aftermath of the Iraq war may reduce the likelihood that he can persuade consumers, or environmental protesters, to accept it.

The panel, which included representatives from the biotechnology industry and conservation organizations as well as university scientists, struggled to reach a consensus, its members say. On the way, they digested more than 600 papers, lost a panel member, and survived a series of last-minute revisions that threatened to scupper the entire project.

"It's a minor miracle that the report got put together," says panel member Mike Gasson, head of food-safety science at the Institute of Food Research in Norwich. Carlo Leifert, an expert in organic agriculture at the University of Newcastle-upon-Tyne, quit the panel last month.

The panel's report makes some concessions to critics of transgenic food, including, for example, the observation that allergens produced by transgenes may not be spotted during regulatory screening, and may only emerge once a crop is widely grown. But another fear often raised by environmental groups - that transgenic crops could give rise to herbicide-resistant 'superweeds' was played down in the report.

Members were also split on whether extensive growth and consumption of such crops in the United States constitute evidence that they are safe to eat. The panel eventually agreed that the available research shows risks to human health to be "very low".

A large-scale study of the impact of herbicide-tolerant transgenic crops on biodiversity, conducted by a team of UK-based scientists (see Nature 412, 760-763; 2001), is currently undergoing peer review, and the panel said it was reluctant to draw conclusions about environmental risks in the meantime. The panel said, however, that "the most important issue is [the crops'] potential effect on farmland and wildlife", and pledged to update its report after the biodiversity study is published.

www.gmsciencedebate.org.uk 